\title{
МРНТИ 44.29
}

УДК 621.365

https://doi.org/10.51889/2020-4.1728-7901.19

\author{
Ғ.П. Қальимбетов ${ }^{1,2}$, А.Ж. Тойгожинова ${ }^{1,2}$ \\ ${ }^{1}$ Хальққаральққ ақұпараттандыру академиясы, Алматы қ., Қазақсттан \\ ${ }^{2}$ М. Тыныишбаев атындавы Қазақ көлік және коммуникация академиясы, Алматы қ., Қазақстан
}

\section{КӨПФУНКЦИОНАЛДЫ ЭНЕРГЕТИКАЛЫҚ КЕШЕНДЕРДІҢ (КЭК) ҚҰРАМЫНДАҒЫ ЖЕЛ ЭЛЕКТР ГЕНЕРАТОРЫ ЖҰМЫС РЕЖИМДЕРІНІҢ ӨНДІРІЛЕТІН ҚУАТТҚА ТӘУЕЛДІЛІГІ}

\begin{abstract}
Аңъдатпа
Жел энергиясын пайдалану коэффициенті (Бетц-Жуковский критерийі) жел дөңгелегі жазықтығынан өткенде желдің жылдамдығының жоғалуына байланысты. Жел турбинасы өндіретін куат жел дөңгелегі шығарған қуаттан қалпына келтірілген жел энергиясын пайдалы энергияға айналдыру кезіндегі шығындар мөлшерімен ерекшеленеді. Жел турбинасының қуатын таңдау қарастырылып отырған объектіде қолданылатын электр тұтынушыларының электр жүктемесімен анықталады. Олар ешқашан бір уақытта қосылмайтынын есте ұстаған жөн. Сондықтан есептеу электр энергиясын тұтынудың орташа көрсеткіштері бойынша жүзеге асырылады. Жұмыста жел турбиналарының жұмыс режимі жүктеме қуатын шектемей қарастырылған. Ұқсас жүйе жел турбинасы торда жұмыс істегенде немесе артық қуатты тастауға арналған техникалық құрылғылар болған кезде қолданылады. Электромеханикалық жүйені оңтайлы режимде автоматты тұрақтандырудың анықталған әсері, сөзсіз, жел турбинасын жасау тұжырымдамасының маңызды артықшылықтарының бірі болып табылады. Модельдеу нәтижелерін кластерлік режимде жел турбиналарын басқаруды оңтайландыру үшін пайдалануға болады.
\end{abstract}

Түйін сөздер: жел турбинасы, жылдамдық, қуат, газ құбыры, энергия.

\author{
Аннотация \\ Г. П. Калимбетов ${ }^{1,2}$, А. Ж. Тойгожинова ${ }^{1,2}$ \\ ${ }^{1}$ Международная академия информатизачии, г.Алматы, Казахстан \\ ${ }^{2}$ Казахская акдемия транспорта и коммуникаичи имени М. Тынышпаева, г.Алматы, Казахстан \\ ЗАВИСИМОСТЬ ГЕНЕРИРУЕМОЙ МОЩНОСТИ ОТ РЕЖИМОВ РАБОТЫ ВЕТРОВОГО \\ ЭЛЕКТРИЧЕСКОГО ГЕНЕРАТОРА В СОСТАВЕ МНОГОФУНКЦИОЛНАЛЬНОГО \\ ЭНЕРГЕТИЧЕСКОГО КОМПЛЕКСА
}

Коэффициент использования энергии ветра (критерий Бетца - Жуковского) зависит от величины потери скорости ветра при прохождении его через плоскость ветроколеса. Мощность, вырабатываемая ветроустановкой, отличается от мощности, развиваемой ветроколесом, на величину потерь при преобразовании утилизируемой энергии ветра в полезную энергию. Выбор мощности ВЭУ определяется электрической нагрузкой электропотребителей, которые используются в рассматриваемом объекте. При этом следует учитывать, что все они практически никогда не включаются одновременно. Поэтому расчет ведется по средним показателям электропотребления. Работа предусматривает работу ветряных турбин без ограничения грузоподъемности. Подобная система используется при работе ветряной турбины в сети или при наличии технических устройств на превышение мощности. Выявленный эффект автоматической стабилизации электромеханической системы в оптимальном режиме, несомненно, является одним из важных преимуществ концепции ВЭУ. Результаты моделирования могут быть использованы для оптимизации управления ветряными турбинами в кластерном режиме.

Ключевые слова: ветротурбина, скорость, мощность, газопровод, энергия.

\section{Abstract \\ DEPENDENCE OF THE GENERATED POWER ON THE OPERATING MODES OF THE WIND ELECTRIC GENERATOR AS PART OF THE MULTIFUNCTIONAL ENERGY COMPLEX Kalimbetov G.P. ${ }^{1,2}$, Toigozhinova A. Zh. ${ }^{1,2}$ \\ ${ }^{1}$ International Informatization Academy, Almaty, Kazakhstan \\ ${ }^{2}$ Kazakh Academy of Transport and Communications named after M. Tynyshpayeva, Almaty, Kazakhstan}

The wind energy utilization factor (Betz-Zhukovsky criterion) depends on the loss of wind speed when it passes through the plane of the wind wheel. The power generated by the wind turbine differs from the power developed by the wind wheel by the amount of losses when converting the recovered wind energy into useful energy. The choice of wind turbine power is determined by the electrical load of electrical consumers that are used in the facility under 
consideration. It should be borne in mind that they almost never turn on at the same time. Therefore, the calculation is carried out according to the average indicators of power consumption.

The work involves the operation of wind turbines without limiting the carrying capacity. A similar system is used when a wind turbine is operating in the network or in the presence of technical devices for exceeding the power. The revealed effect of automatic stabilization of the electromechanical system in the optimal mode is undoubtedly one of the important advantages of the WPP concept. The simulation results can be used to optimize the control of wind turbines in cluster mode.

Keywords: wind turbine, speed, power, gas pipeline, energy.

Бұл коэффициенттің максималды мәні 0,593 құрайды, яғни. жел турбинасы жел ағынының жартысынан сәл астамын қолдана алады. Нақты көлденең осьті жел турбиналары үшін $\xi=0,42$, тік осьтік үшін $\xi=0,38$. Жел жылдамдығы - бұл жел турбиналарының қуатын есептеудің анықтаушы параметрі, өйткені ол тек осы жылдамдыққа тәуелді. Жел турбинасының жұмысы келесі жылдамдықтармен сипатталады:

$\mathrm{v}_{\min }$ - бұранда айнала бастайтын минималды (басталатын) жел жылдамдығы; $\mathrm{v}_{\mathrm{p}}$ - жел турбинасы жұмыс режиміне еніп, номиналды қуатты дамытатын жобалық (номиналды) жылдамдық;

$\mathrm{v}_{\max }$ - жел турбинасын өшіру керек желдің максималды жылдамдығы.

$\mathrm{V}_{\text {min-ден }} \mathrm{v}_{\mathrm{p}}$-ге дейінгі жылдамдық аралығында жел турбинасы қуатты дамытады, соғұрлым желдің жылдамдығы жоғары болады. Желдің жылдамдығы $v \geq v_{\mathrm{p}}$ кезінде бұранданың тұрақты айналу режимі автоматты түрде арнайы реттегіш құрылғының көмегімен орнатылады. Егер $\mathrm{v}>\mathrm{v}_{\max }$ болса, жел турбинасындағы желдің қысымы критикалық болады және механикалық беріктік жағдайына байланысты ол жүздердің шабуыл бұрышын реттеу арқылы тоқтайды.

Жел турбинасы өндіретін куат жел дөңгелегі шығарған куаттан қалпына келтірілген жел энергиясын пайдалы энергияға айналдыру кезіндегі шығындар мөлшерімен ерекшеленеді.

Жел турбинасының қуатын таңдау қарастырылып отырған объектіде қолданылатын электр тұтынушыларының электр жүктемесімен анықталады. Олар ешқашан бір уақытта қосылмайтынын есте ұстаған жөн. Сондықтан есептеу электр энергиясын тұтынудың орташа көрсеткіштері бойынша жүзеге асырылады. Сонымен қатар, электр энергиясын тұтыну тәуліктің уақытына байланысты. Мысалы, түнде энергияны тұтыну азаяды, ал жел турбинасының жұмысы жалғасуда. Осылайша, тұтынудың төмендеуі кезеңінде энергияны сақтауға мүмкіндік беретін жинақтау қондырғыларын қамтамасыз ету қажет, содан кейін жинақталған энергияны ең жоғары жүктемелер кезеңінде пайдалануға болады.

Жел дөңгелегі торлайтын ауданы:

$$
A=\frac{\pi D^{2}}{4}, M^{2}
$$

мұндағы D - жел дөңгелегінің диаметрі, м.

Жел турбинасы өндіретін куат:

$$
P=\rho \frac{A}{2} v^{3} \cdot \xi \cdot \eta, \mathrm{Bт}
$$

мұндағы:

$\rho$ - ауа тығыздығы 1,23 кг/м³ -ке тең;

v - желдің жылдамдығы, м/с;

$\xi$ - жел энергиясын пайдалану коэффициенті;

$\eta$ - бұл жел дөңгелегі білігінен жұмыс машинасына электр куатын беру кезіндегі шығындарды ескеретін коэффициент (жел турбинасының тиімділігі), ол анықталады:

$$
\eta_{n}=\eta_{p} \eta_{\mathrm{r}}
$$

мұндағы пр - беріліс қорабының тиімділігі (механикалық тиімділік); үg - генератордың тиімділігі.

Есептеулер үшін $\eta \mathbf{n}=0,8$ аламыз.

Жел турбинасы өндіретін куат жел турбинасының техникалық сипаттамасында көрсетілген барлық жылдамдық диапазоны бойынша есептеледі. Жел генераторлары мен биоэнергетикалық қондырғылардағы электр машиналары ретінде, әдетте, номиналды жүктеме оның номиналды кернеуде, номиналды токта, номиналды айналу жылдамдығындағы жұмысы болып табылатын 
синхронды генераторлар (СГ) қолданылады. аралас резистивті-индуктивті жүктемеге сәйкес келетін номиналды жиілік және номиналды куат коэффициенті. Басқару сипаттамасы - бұл тұрақты номиналды жүктеме кернеуін, тұрақты жиілікті және куат коэффициентін сақтай отырып қоздыру тогының жүктеме тогына тәуелділігі [1].

1- суретте синхронды генератор үшін автоматты қозуды басқару жүйесінің құрылымын көрсетеді.

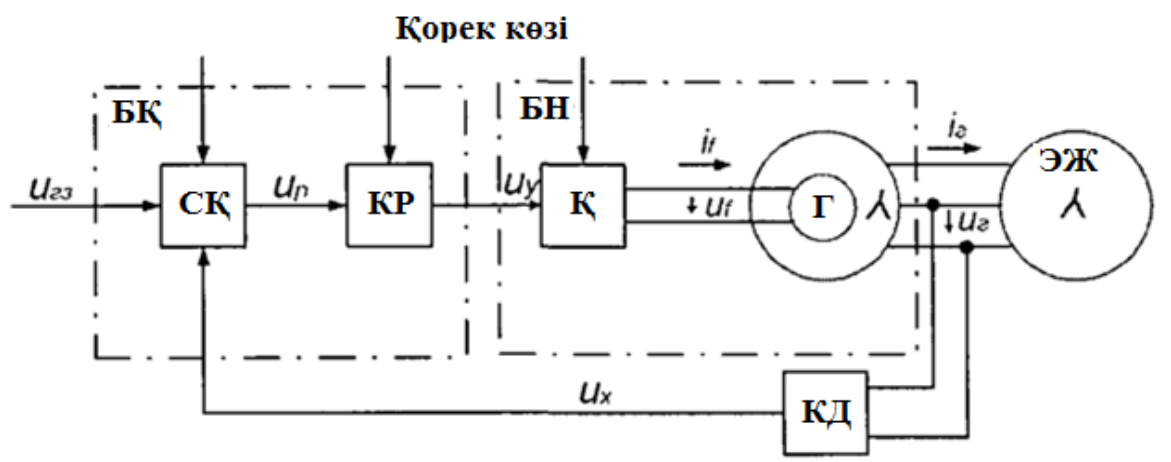

Сурет 1. Синхронды генератордың құзууын автоматты басқару жүйесінің құрылымы

Жүйенің мақсаты - генератордың статор орамасының терминалдарында оның қоздыру орамасындағы ток күшін өзгерту арқылы тұрақты кернеуді ұстап тұру. Жүйедегі басқарылатын айнымалы $\mathrm{x}(\mathrm{t})$ - генератордың кернеуі Ug. Ux кернеуіне пропорционалды Ux сигналы (басқару әрекеті xk (t)) DN кернеу датчигі арқылы жасалады және СҚ салыстыру құрылғысына беріледі, мұнда $\left.\mathrm{Ugz} \mathrm{сілтемесімен} \mathrm{салыстырылады} \mathrm{(басқару} \mathrm{әрекеті} \mathrm{x}^{3}(\mathrm{t})\right)$.

Қате сигналының белгісі мен мәніне байланысты КР кернеу реттегіші қоздырғыш Қ шығысында $i \cdot f$ қоздыру тогын көбейту немесе азайту үшін Uу (басқару әрекеті у $(\mathrm{t}))$ басқару сигналын шығарады. Бұл қоздыру тогы генератордың Ug кернеуін анықтайды, негізгі алаңдаушылық әсері - бұл ЭЖ электр жүйесімен байланыс тізбегіндегі генератордың $\mathrm{i}(\mathrm{t})$ жүктеме тогы. Қоздырғышы В бар синхронды генераторды осы жүйеде басқару объектісі ретінде қарастыруға болады.Одақтың басқару құрылғысына US салыстыру құрылғысы және RN кернеу реттегіші кіреді.

Синхронды генераторлардың басқару сипаттамалары жүктеме тогы өзгерген кезде оның қысқыштарында тұрақты кернеуді ұстап тұру үшін генератордың қоздыру тогының өзгеру заңын анықтайды, яғни. тәуелділікті білдіреді Iw $=\mathrm{f}(\mathrm{I}), \mathrm{U}=$ const, $\mathrm{n}=$ const, $\cos \varphi=$ const.

Есептеу мысалын жүргізейік. (2) формула бойынша, егер D - жел дөңгелегінің диаметрі 3 болса, онда жел дөңгелегі сыпырған аудан $\mathrm{A}=(\pi \mathrm{D} \cdot 2) / 4=7,07$ м2 құрайды. Сонда (3) формула бойынша жел дөңгелегінің жұмыс жылдамдығындағы жел турбинасы өндіретін куат $\mathrm{P}=\rho \mathrm{A} / 2 \mathrm{v}^{3} \cdot \xi \cdot \eta=1,23$ $7.07 / 2 \cdot 73 \cdot 0,42 \cdot 0,8=501,1041$ Вт. Сол сияқты, куат желдің басқа жылдамдықтары үшін $\mathrm{v}_{\min }-$ ден $\mathrm{v}_{\mathrm{p}}$ дейінгі аралықта 1,0 м/с аралықпен есептеледі. $\mathrm{P}=f(\mathrm{v})$ тәуелділігі құрылатын мәліметтер кестеге енгізілген (1-кесте).

Кесте 1. Жел турбинасы қуатының желдің жылдамдыzына тәуелділігін есептеу нәтижелері

\begin{tabular}{|c|c|c|c|c|c|}
\hline$v, M / c$ & 3 & 4 & 5 & 6 & 7 \\
\hline$P, B m$ & 39,44 & 93,5005 & 182,6181 & 315,5641 & 501,1041 \\
\hline
\end{tabular}

Кестеге сәйкес $\mathrm{P}=f(\mathrm{v})$ тәуелділікті оған сипаттық нүктелерді көрсету арқылы құруға болады: $\mathrm{V}_{\min }$, Pmin, $\mathrm{v}_{\mathrm{p}}, \mathrm{Pp}$; vmax.

VEG тиімділігін арттыру принциптері

Ауа массасы анықталады:

$$
m=\rho v S \Delta t
$$

мұндағы $\rho$ - ауа тығыздығы 1,23 кг/м³-ке тең;

v - желдің жылдамдығы, м/с;

$\mathrm{S}$ - аймақ.

Желдің қуаты анықталады: 
Жел турбинасы өндіретін қуат анықталады:

$$
P_{\mathrm{EeT}}=\frac{d E_{C}}{d t}=\rho \frac{s}{2} v^{3}
$$

$$
P_{\mathrm{Typ}}=\frac{d E_{C}}{d t}=\rho \frac{A}{2} v^{3} \cdot \xi \cdot \eta
$$

мұндағы:

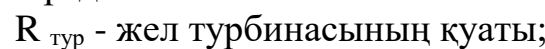

A - бұл жел дөңгелегі алып кеткен аймақ, оған тең:

мұндағы D - жел дөңгелегінің диаметрі, м.

$$
A=\frac{\pi D^{2}}{4}
$$

$\xi$ - жел энергиясын пайдалану коэффициенті;

$\eta$ - бұл жел дөңгелегі білігінен жұмыс машинасына электр куатын беру кезіндегі шығындарды ескеретін коэффициент (жел турбинасының тиімділігі), ол анықталады:

$$
\eta_{n}=\eta_{p} \cdot \eta_{\mathrm{r}}, \quad \eta<1
$$

мұндағы пр - беріліс қорабының тиімділігі (механикалық тиімділік);

$\eta \mathrm{g}$ - генератордың тиімділігі.

Жел турбинасының коэффициенті $\eta$ жылдамдықтың қатынасына және the шабуыл бұрышына тәуелді болады, сонда:

Мұндағы:

$$
\begin{gathered}
\eta=C_{p}(z)=C_{p}(\lambda, \beta) \\
\lambda=\frac{R \omega}{v}
\end{gathered}
$$

$\mathrm{R}$ - жел турбинасының радиусы;

$\omega$ - ротордың айналу жиілігі.

(7) теңдеуді пайдаланып, (9) теңдеуден мынаны аламыз:

$$
P_{\mathrm{Typ}}=\rho \frac{A}{2} v^{3} C_{p}(z), \mathrm{BT},
$$

А дөңгелегінің радиусы R арқылы өтіп жатқан аумақты білдіре отырып, біз жел турбинасы моментінің өрнегін аламыз:

$$
M_{\mathrm{TYp}}=\frac{\mathbb{P}_{\mathrm{Typ}}}{\omega}=\frac{\rho \pi R^{2} v^{\mathrm{g}} C_{\mathrm{p}}(z)}{2 \omega}
$$

Жел турбинасының динамикасы қозғалыс теңдеуімен сипатталады:

$$
I \frac{d \omega}{d t}=M_{\mathrm{TYp}}(v, \omega)-M_{T O P}\left(P_{\mathrm{TYp}}, \omega\right)-M_{T P}(\omega)
$$

Мұндағы:

J - жел турбинасының айналмалы массаларының инерция моменті;

MTOP (Рmyр, $\omega)$ жел турбинасының айналу кинетикалық энергиясын таңдау нәтижесінде туындаған жалпы тежеу моменті;

MTP $(\omega)$ - механикалық шығындар моменті.

MTur UR генераторының айналу моменті жел турбинасының электр жабдықтарымен жел турбиналарының жылдамдығын субординальды реттеу циклында берілген крутящий момент деңгейінде реттеу арқылы орнатылады.

VEG-ден алынған куат графигін (2 - суретте) төрт аймаққа бөлуге болады:

1 аймақ - жел турбинасы сөнген;

2-аймақ, 
3-аймақ - жел турбинасы қосулы, басқару жүйесі электр қуатын өндірудің максималды режимін қамтамасыз етеді;

4 аймақ - қауіпсіздік мақсатында өшірілген жел турбинасы.

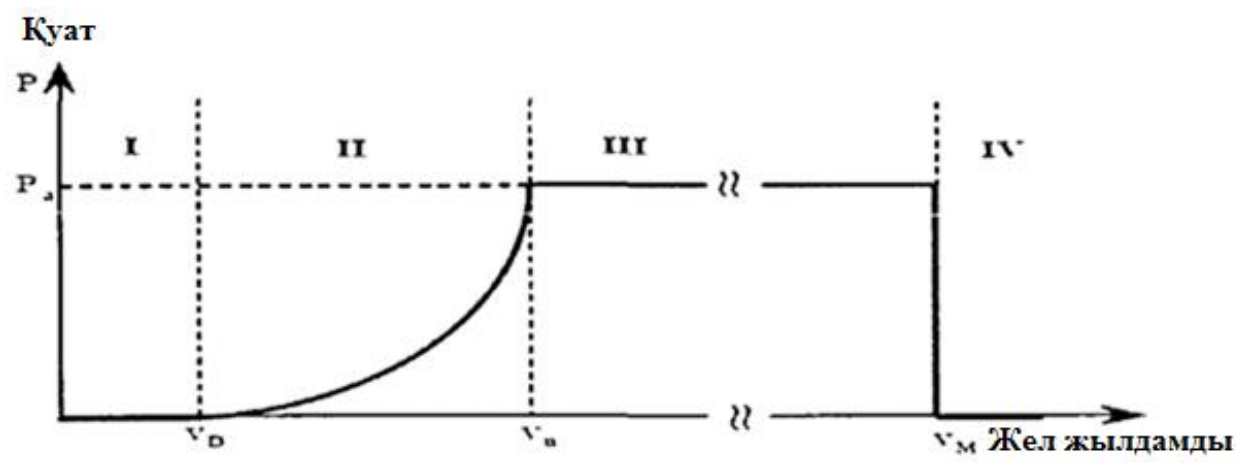

Сурет 2. VEG-тен қуат алатын аймақтар

$\lambda_{\text {опm }}$ алдыңғы теңдеулердің көмегімен, ал $\omega_{\text {опm }}$ келесі түрде есептеледі:

$$
\omega_{\mathrm{omr}}=\frac{\lambda_{\mathrm{omm}} \otimes v}{R}
$$

және мәні бойынша салыстырылады. Егер $\omega$ қосу $\omega$-ден үлкен болса, жүктеме кернеуі нөлге тең болады. Ағым төмендейді және турбинаның үдеуі кезінде жел турбинасының электромагниттік моменті де төмендейді. Егер $\omega_{\text {opt }} \omega$-ден аз болса, онда жүктеме кернеуі қалыпты түрде орнатылады және турбина жылдамдығы баяулайды [2].

2- кестеде жел турбинасының параметрлерін басқару кезінде алынған қуаттың нәтижелерін көрсетеді.

Кесте 2. Куат нәтиже алды

\begin{tabular}{|c|c|c|c|}
\hline $\begin{array}{l}\text { Параметрлермен } \\
\text { басқару }\end{array}$ & $\begin{array}{l}\text { Алььнван қуат } \\
\text { (кBm) }\end{array}$ & $\begin{array}{l}\text { Стандарттыь } \\
\text { қуат (кBт) }\end{array}$ & Тиімділігі (\%) \\
\hline Тек шабуыл бұрымиымен & 62,003 & 78,214 & 12,083 \\
\hline Тек ЖЭК бавытымен & 13,295 & 63,979 & 2,591 \\
\hline $\begin{array}{l}\text { Шабуыл бұрышы және } \\
\text { бавытымен }\end{array}$ & 75,197 & 92,316 & 14,654 \\
\hline
\end{tabular}

Жұмыста жел турбиналарының жұмыс режимі жүктеме қуатын шектемей қарастырылған. Ұқсас жүйе жел турбинасы торда жұмыс істегенде немесе артық қуатты тастауға арналған техникалық құрылғылар болған кезде қолданылады. Электромеханикалық жүйені оңтайлы режимде автоматты тұрақтандырудың анықталған әсері, сөзсіз, жел турбинасын жасау тұжырымдамасының маңызды артықшылықтарының бірі болып табылады. Модельдеу нәтижелерін кластерлік режимде жел турбиналарын басқаруды оңтайландыру үшін пайдалануға болады [3].

Әдетте газ тәрізді отын қоймадан немесе өндіріс орнынан тұтынушыға азды-көпті тармақталған құбыр желілері (газбен жабдықтау желісі) арқылы жеткізіледі.

Құбырдың ішінде газ қысымға ұшырайды: магистральды газ құбыры үшін бірнеше ондаған штангалардан газ соңғы тұтынушыға (электр генераторы және / немесе жылытқыш) жеткізілетін құбырдағы бірнеше ондаған миллибарға дейін [4].

Газ тәрізді отынды тарату желілеріндегі басты проблема қысымның тұрақсыздығы болып табылады. Газ қысымының өзгеруі оттықтың қалыптан тыс жұмысына әкеліп соғады, соның ішінде. Газ қысымының күрт өзгеруімен (әсіресе төмендеуімен), оттықтың қуаттылығының сөнуіне дейін төмендеуі мүмкін. Осындай проблемаларды болдырмау үшін оттықтың басындағы газ қысымы:

- оттықтың басындағы қысымның жоғалуын және генератордың жану камерасындағы аэродинамикалық кедергісін (жылу генераторы және/немесе электр генераторы) өтей алатын минималды қажетті қысымнан артық болуы керек; 
- өндіруші көрсеткен шекті рұқсат етілген қысымнан аз болуы;

- тұрақты болыңыз және параметрге сәйкес келіңіз.

Бұған қол жеткізу үшін газ тәрізді отын жанарғыға басқару және қауіпсіздік құралдары сериясы арқылы жеткізіледі, оларды жалпы түрде «газ пойызы» деп атайды.

Келесі 3-суретте газ пойызының функционалдық сызбасын көрсетеді.

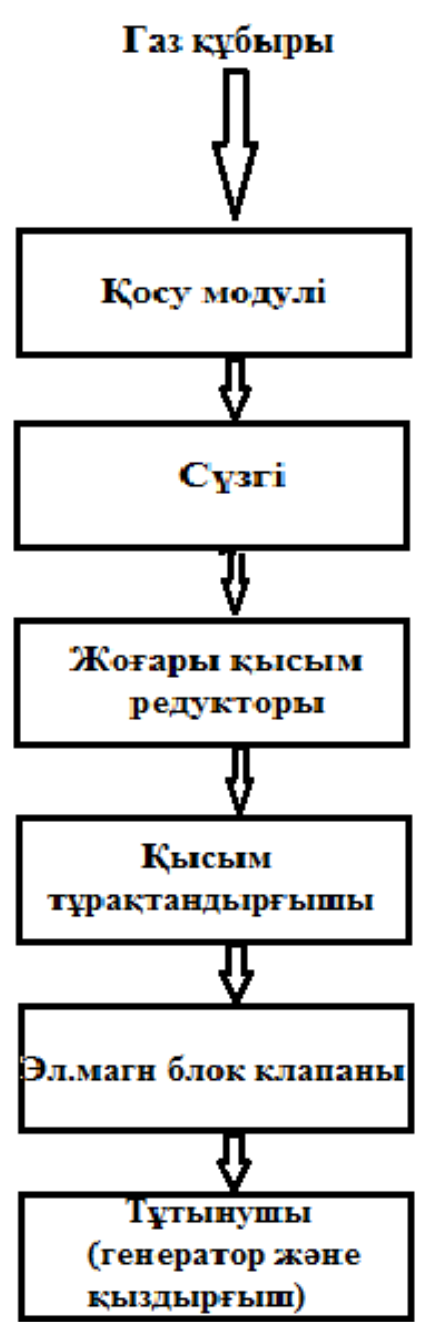

Сурет 3. Газ пойызының қ̧ызметтік сызбасы
Байланыс модулі оттықтың жұмысы кезінде пайда болатын дірілдің газбен жабдықтау желісіне өтуін болдырмауға қызмет ететін қолмен жабылатын клапаннан және дірілге қарсы қосқыштан тұрады. Сүзгі газ тәрізді отында болуы мүмкін механикалық қоспаларды ұстауға қызмет етеді. Қысым тұрақтандырғышы магистральдық газ құбырынан келетін газдың қысымын төмендетуге және одан келетін газдың қысымына және сыйымдылығына қарамастан, одан шығатын жерде тұрақты газ қысымын ұстап тұруға қызмет етеді. Қысымды төмендету және тұрақтандыру мембраналық типтегі қондырғының көмегімен жүзеге асырылады, онда серіппенің қысылу коэффициентін өзгерту арқылы дроссель клапаны теңестіріледі және тұрақтандырғыштың шығысында қажетті қысым орнатылады. Осы типтегі қысым тұрақтандырғышы газ құбырындағы қысым 500 мбардан төмен болса қолданылады. Газ құбырындағы қысым 500 мбардан жоғары болған кезде қосымша қысымды төмендеткішті қолдану қажет, ол қосымша қорғаныс сөндіргіш клапанымен (SSV), сақтандырғыш клапанымен (PSK) және оған дейінгі және кейінгі қысымды көрсететін және манометрді визуалды басқаруға қызмет ететін манометрлермен жабдықталған. Стабилизатор үшін рұқсат етілген кіріс қысымдары және онда орнатылған серіппеге және нақты куатқа байланысты қажетті қысымды таңдауға болатын шығыс қысымының ауқымы бар. Магистральдық газ құбырындағы қысым редуктордан кейін орналасқан қондырғылардың өндірушілері көрсеткен ең жоғары рұқсат етілген мәннен жоғары болған кезде жоғары қысымды төмендеткіш пен қауіпсіздік құрылғылары қажет. Егер газбен жабдықтау желісіндегі қысым өндіруші көрсеткен ең жоғары рұқсат етілген қысымнан аз болса (әдетте 300-ден 500 мбар аралығында) [5-8].

Жоғары қысымды төмендеткіш қажет емес, тек тұрақтандырғыш қажет. Электромагнитті клапан блогы қауіпсіздік сөндіргіш клапанынан, басқару клапанынан (айнымалы жұмсақ саңылау) және минималды газ қысым қосқышынан тұрады. 1200 кВт-тан жоғары оттықтар үшін EN676 клапан блогының герметикалығын бақылаумен толықтырылуын қарастырады. Басқару блогы әрбір жанар алдында және әр оттық өшірілгеннен кейін екі клапанның жабылуының тығыздығын тексеру үшін қолданылады. Шағын және орташа қуатты оттықтар үшін газ модулінің жоғарыда сипатталған барлық элементтері, байланыс модулі мен жоғары қысымды редуктордан басқа, бір корпуста орналасуы мүмкін. Мұндай құрылғы тұрақтандырғыш және апаттық өшіру функцияларын орындайды және газды көп блокты деп аталады.

Клапан блоктары орнатылатын оттықтың дизайнына байланысты екі типті болуы мүмкін:

1. Бір сатылы;

2. Екі сатылы.

Бір немесе басқа клапан блогының түрін пайдалану оттықтың дизайнына байланысты.

Газ пойызында фильтрдің шығысындағы, клапан блогының шығысындағы және оттық басындағы қысымды өлшеуге арналған бірнеше байланыс бар. Бензин пойызын оттыққа қосу үшін байланыс адаптері қажет. Егер газ беру желісіндегі газ қысымы рұқсат етілген шекті мәннен аз болса, онда жоғары қысымды төмендеткіш қажет емес. Бұл жағдайда бензин пойызы көп блок ретінде жеткізілуі 
мүмкін. Газ пойызы пойыздың кірісіне ең төменгі қажетті газ қысымы негізінде таңдалады, пойыздың өзі, оттықтың басы мен генераторлардың (жылу генераторы және/немесе электр генераторы) қарсылығын жеңуге жеткілікті [9-11].

Оттықта генераторлардың бүкіл газбен жабдықтау жүйесін (жылу генераторы және/немесе электр генераторы) орнатуда және реттеуде маңызды рөл атқаратын бірқатар компоненттер бар. Атап айтқанда, газ және қосарланған отынды қыздырғыштарда газ ағынын реттейтін дроссельдік клапан (демпфер) орнатылған. Бұл клапан сервомотор арқылы ауыспалы профильді механикалық эксцентрик арқылы қозғалады [12-15].

Қорытынды: Сыйымдылығы жоғары газ оттықтарында, әдетте, газ қысымының максималды қосқышы орнатылған. Егер газ беру құбырындағы қысым рұқсат етілген қысымнан асып кетсе, оттықты өшіреді.

Пайдаланылван ддебиеттер тізімі

1 Стратегия эффективного использования энергии и возобновляемых ресурсов Республики Казахстан в целях устойчивого развития до 2024 года. Астана, 2010. (http://adilet.zan.kz/rus/docs/P080000060_).

2 Школьник В., Перспективы энергетики Казахстана в свете мировых тенденции энергетического развития. Kazenergy №8-9(11), 2007.

3 Капля Е.В. Автоматическая система ориентаиии солнечной батареи в условиях переменной освещенности// Известия ВолгГТУ. - Волгоград - 2009.--№8(56)-. С.88.

4 Князевский Б.А., Электроснабжение промышленных предприятий. - М.: Высшая шккола, 2011, 258.

5 Киреева Э.А. и др. Электроснабжение цехов промылиленных предприятий. -М.: НТФ Энергопрогресс, Энергетик, 2003г. 1206.

6 Kalimbetov G.P., Toygozhinova A. Zh. Analysis of energy sources using the force of the wind and methods of increasing their efficiency Алматы 2020, Вестник КазНИТУ, 6 (142), 265-270сmp.

7 Калимбетов Г.П., Тойгожинова А. Ж. Вопросы и надежность электроэнергетики республики Казахстан. Сборник научных трудов по материалам Международной научно-практической конференции 12 октября 2020 г. / Под общ. ред. Е. П. Ткачевой. - Белгород: ООО Агентство перспективных научных исследований (АПНИ), 2020. -17-21c.

8 Тойгожинова А.Ж., Калимбетов Г.П., Джексенбаев Е.К. Разработка структурных схем системы автоматического управления МЭК. Материалы международной научно - практической конференции «Наука и жизнь - 2019» часть 11. Прага. Прага, 20192. 8-12 cmp.

9 Шиняков Ю.А., Шурыгин Ю.А., Аркатова О.Е. Повымение энергетической эффективности автономных фотоэлектрических энергетических установок // Электроника, Измерительная Техника, Радиотехника и Связь. Доклады ТУСУРа, № 2 (22), часть 2, декабрь 2010 - С. 102.

10 Шиняков Ю.А., Шурыгин Ю.А., Аркатова О.Е. Повышение энергетической эффективности автономных фотоэлектрических энергетических установок // Электроника, Измерительная Техника, Радиотехника и Связь. Доклады ТУСУРа, № 2 (22), часть 2, декабрь 2010 - С. 102.

11 Тойгожинова А. Ж., Калимбетов Г.П. Международное научно - педагогическое издание. Автономные системы электроснабжения. Высшая школа Казахстана. 4/2019. Алматы 2019. 190-196 стр.

12 Наумов А.В., Плеханов С.И. Развитие солнечной энергетики на основе тонкопленочных CIGSэлементовтЭнергия: экономика, техника, экология. - М., 2013. -№ 7. - С. 14.

13 Калимбетов Г.П., Тойгожинова А.Ж., Средства ориентаиии и анализ способов солнечных панелей. Вестник КазАТК 3(114) 2020г. г. Алматы. 206-213 с.

14 Кузнецов Ф.А., Резниченко М.Ф. Кремний для солнечной энергетики// Материалы электронной техники. - 2009. - №4. - C.4.

15 Solarsoul [Электронный ресурс] - http://solarsoul.net/treker-dlya-fotoelektricheskix-ustanovok

References:

1 Strategija jeffektivnogo ispol'zovanija jenergii $i$ vozobnovljaemyh resursov Respubliki Kazahstan v celjah ustojchivogo razvitija do 2024 goda (2010) [Strategy for the effective use of energy and renewable resources of the Republic of Kazakhstan for sustainable development until 2024]. (http://adilet.zan.kz/rus/docs/P080000060). (In Russian)

2 Shkol'nik V., (2007) Perspektivy jenergetiki Kazahstana v svete mirovyh tendencii jenergeticheskogo razvitija [Prospects of Kazakhstan's energy sector in the light of global trends in energy development. Kazenergy]. Kazenergy №8-9(11). (In Russian)

3 Kaplja E. V. (2009) Avtomaticheskaja sistema orientacii solnechnoj batarei v uslovijah peremennoj osveshhennosti [Automatic solar battery orientation system in variable light conditions]. Izvestija VolgGTU.Volgograd, №8(56), 88. (In Russian) 
4 Knjazevskij B.A., (2011) Jelektrosnabzhenie promyshlennyh predprijatij.M.Vysshaja shkola, 258. (In Russian)

5 Kireeva Je.A. i dr. (2003) Jelektrosnabzhenie cehov promyshlennyh predprijatij [Power supply of workshops of industrial enterprises. M.: NTF Energoprogress]. M.NTF Jenergoprogress, Jenergetik, 120. (In Russian)

6 Kalimbetov G.P., Toygozhinova A. Zh. (2020) Analysis of energy sources using the force of the wind and methods of increasing their efficiency Almaty 2020 [Analysis of energy sources using the force of the wind and methods of increasing their efficiency Almaty 2020], Vestnik KazNITU, 6 (142), 265-270. (In Russian)

7 Kalimbetov G.P., Tojgozhinova A. Zh. (2020) Voprosy i nadezhnost' jelektrojenergetiki respubliki Kazahstan. [Questions and reliability of the electric power industry of the Republic of Kazakhstan]. Cbornik nauchnyh trudov po materialam Mezhdunarodnoj nauchno-prakticheskoj konferencii 12 oktjabrja 2020 g. Pod obshh. red. E. P. Tkachevoj. Belgorod: OOO Agentstvo perspektivnyh nauchnyh issledovanij (APNI), 17-21. (In Russian)

8 Tojgozhinova A. Zh., Kalimbetov G.P., Dzheksenbaev E.K. (2019) Razrabotka strukturnyh shem sistemy avtomaticheskogo upravlenija MJeK [Development of structural schemes of the IEC automatic control system]. Materialy mezhdunarodnoj nauchno - prakticheskoj konferencii «Nauka i zhizn 2019» chast' 11. Praga. Praga, 8-12. (In Russian)

9 Shinjakov Ju.A., Shurygin Ju.A., Arkatova O.E. (2010) Povyshenie jenergeticheskoj jeffektivnosti avtonomnyh fotojelektricheskih jenergeticheskih ustanovok [Improving the energy efficiency of autonomous photovoltaic power plants]. Jelektronika, Izmeritel'naja Tehnika, Radiotehnika i Svjaz'. Doklady TUSURa, № 2 (22), chast' 2, dekabr' 2010, 102. (In Russian)

10 Shinjakov Ju.A., Shurygin Ju.A., Arkatova O.E. (2010) Povyshenie jenergeticheskoj jeffektivnosti avtonomnyh fotojelektricheskih jenergeticheskih ustanovok [Improving the energy efficiency of autonomous photovoltaic power plants]. Jelektronika, Izmeritel'naja Tehnika, Radiotehnika i Svjaz'. Doklady TUSURa, № 2 (22), chast' 2, 102. (In Russian)

11 Tojgozhinova A. Zh., Kalimbetov G.P. (2019) Mezhdunarodnoe nauchno - pedagogicheskoe izdanie. Avtonomnye sistemy jelektrosnabzhenija [International scientific and pedagogical publication. Autonomous power supply systems]. Vysshaja shkola Kazahstana. Almaty 2019, 190-196. (In Russian)

12 Naumov A.V., Plehanov S.I. (2013) Razvitie solnechnoj jenergetiki na osnove tonkoplenochnyh CIGSjelementovtJenergija: jekonomika, tehnika, jekologija [Development of solar energy based on thin-film CIGSelementsenergiya: ekonomika, tekhnika, ekologiya]. M. № 7, 14. (In Russian)

13 Kalimbetov G.P.,Tojgozhinova A.Zh. (2020) Sredstva orientacii i analiz sposobov solnechnyh panelej [Means of orientation and analysis of methods of solar panels]. Vestnik KazATK 3(114), 206-213. (In Russian)

14 Kuznecov F.A., Reznichenko M.F. (2009) Kremnij dlja solnechnoj jenergetiki [Silicon for solar energy]. Materialy jelektronnoj tehniki. №4, 4. (In Russian)

15 Solarsoul [Jelektronnyj resurs]. http://solarsoul.net/treker-dlya-fotoelektricheskix-ustanovok (In English) 